\title{
EFFECTS OF MIGRANT REMITTANCES ON FARM HOUSEHOLD WELFARE IN NIGERIA
}

\author{
Egbe BASSEY ETOWA ${ }^{1}$, Noble J. NWEZE ${ }^{2}$, Chukwuemeka J. ARENE ${ }^{2}$
}

\author{
Address: \\ 1 Department of Agricultural Economics and Extension, University of Port Harcourt, Choba, Rivers State, Nigeria \\ 2 Department of Agricultural Economics, University of Nigeria, Nsukka, Nigeria \\ *Corresponding Author, E-mail: egbetowa@yahoo.com, egbe.etowa@uniport.edu.ng
}

\begin{abstract}
International remittances are now a mechanism in development financing and a welfare strategy. Growing trends of these money transfers by migrants to their families back home in developing nations have been proven by evidences in literature and many empirical findings. This research analysed the effects of migrant remittances on the welfare of farm households in Nigeria. Welfare was measurable in terms of the households' real per capita consumption. Cross sectional data were pooled from two sources. The data sources were Nigerian General Household Survey conducted in 2010/2011 and the Nigerian Living Standard Survey carried out in 2003/2004. The analytical technique adopted was the poverty profile function within the framework of multiple regression analysis. Results showed that four exogenous variables, including household real per capita remittances were significant determinants of household real per capita consumption (welfare).
\end{abstract}

Keywords: Migrant, Remittances, Altruism, Farm, Household, Welfare

JEL: D64

\section{INTRODUCTION}

Basic to this research is the theory of altruism. The altruistic model supposes that a migrant derives satisfaction from the welfare of his/her relatives, implying that migrants send remittances out of affection and responsibility towards the family. The underlying the motive for remittances transfer in this model suggests that there is a no "quid pro quo" in the remittance flows. Thus, remittances are defined as transfers in the balance of payment accounting.

Addison (2004) affirmed that the altruistic model advances a number of hypotheses. First, the amount of remittances should increase with an increase in the migrant's income. Second, the amount of remittances should increase with a decrease in the domestic income of the family or vice versa. And third, remittances should decrease over time as an attachment to the family gradually weakens. The second hypothesis portrays that the poorer family receives more remittances making it an important mechanism in attempting to tackle issues of poverty and welfare in rural areas.

Remitting for households' welfare, can also in part, be explained by the theory of implicit family agreement for risk diversification. Families send some of its members abroad to diversify economic risks. Families will often send their member abroad when economic risks between the sending and foreign country are not positively correlated. The migrant, then, can help to support his family in bad times at home. Conversely, for the migrant, having a family in the home country is insurance as bad times can also occur in a foreign country. In this model, migration becomes a co-insurance strategy with remittances playing the role of an insurance claim. Hence, remittances can be viewed as a livelihood cum risk-coping strategy for smoothing consumption within families. Remittances as spatial risk-sharing mechanism reduce the covariance of the migrant households' aggregate income (Paulson, 1994; Seiler, 1998 as cited in Pleitez-Chavez, 2004).

Freidman's permanent income and Modigliani's life-cycle hypotheses theorise the relationship between the incremental income from remittances and households' consumption. Both permanent and life cycle models make similar predictions about the consumption effects of permanent and temporary changes in a household's income. In summary, both hypotheses postulate that, as opposed to a permanent increase, a temporary increase in income is expected to yield a smaller increase in consumption. Households tend to spread a temporary increase in income over their lifetime consumption. Remittances can be considered a temporary income because among other reasons; they may decrease or cease over time as the migrants attachment to the origin family gradually weakens. Hence, the null hypothesis proposed for this research, "international remittances have no significant effect on households' consumption" is rooted in the permanent income and life cycle hypotheses. Household's consumption refers to the temporal or short term consumption.

Often many researchers have a narrow definition of welfare; this work adopts a broad-brush approach in 
the conceptualisation of welfare. It encompasses several elements of household utility. These are not limited to food and non-food household supplies, but also includes education, health care, shelter, water, electricity, communication related utilities or households expenditure. Hence, welfare in this context represents total wellbeing of remittance recipient households measurable in terms of the households' utility subject to budget constraints or the household's per capita consumption expenditure (Duong, 2003). Whereas income forecasts welfare, values of household per capita consumption expenditure reflect the actual welfare.

As Lennart Bage, the president of IFAD put it: "Remittances represent a lifeline to struggling economies.” It does not only fuel the commercial and service sectors, but also forms the backbone of the individual and household purchasing power (UN, 2003). Households spend the vast majority of remittances received on their basic needs such as food, clothing and shelter. This consumption, combined with investment in health care and education, constitutes 80-90 per cent of remittance spending (IFAD, 2007).

Consumption smoothening forms most of the budget from remittance income because of the altruistic motive of remitters. Based on the statistics of Migration Policy Institute (2014) in Table 1, these remitters are predominantly immigrants in the United States (U.S.) and the United Kingdom (U. K.). Additionally, domestic remitters spread across the entire Nigerian Nation.

Table 1: Remittance inflows to Nigeria by sending country and Nigerian Emigrants Populations, 2012

\begin{tabular}{lrr}
\hline Sending Countries & $\begin{array}{r}\text { Remittances } \\
\text { (\$Millions) }\end{array}$ & $\begin{array}{r}\text { Emigrant } \\
\text { Populations }\end{array}$ \\
\hline United States & 6100.0 & 252000 \\
United Kingdom & 3800.0 & 184000 \\
Chad & 1400.0 & 13000 \\
Italy & 1300.0 & 48000 \\
Cameroon & 961.9 & 116000 \\
Spain & 933.5 & 37000 \\
Germany & 613.4 & 23000 \\
Ireland & 607.5 & 19000 \\
Benin & 580.2 & 43000 \\
Cote d'Ivoire & 474.2 & 44000 \\
Canada & 454.0 & 19000 \\
Sudan & 418.2 & 15000 \\
Niger & 366.7 & 20000 \\
Saudi Arabia & 328.9 & 15000 \\
Gabon & 277.8 & 23000 \\
\hline Source: Migration
\end{tabular}

Source: Migration Policy Institute (2014)

Majority of Remitters in the US and UK are young and highly educated professionals. However, remitters who send money more frequently and at any cost include: those in the lower income brackets, those who have a closer ties to Nigeria, those who have migrated temporarily and women who migrated because of desperate economic reasons (Osili and 2007; Orozco and Millis, 2007 and MPI, 2014).

Although remittances are a more reliable source of funds for the poor than other conventional means, its effects on households' welfare remains a speculation in the rural Nigerian context. Minimal research attention has been devoted to the welfare effects of remittance income in developing countries (e.g. works of Adams and Page, 2005; Adams, 2004, Guptal et al., 2009), including Nigeria. Data on the use of remittances is highly varied depending on the individual household. Variability of remittance data depends on the structure of the local economy, exchange rates and political stability among other factors (Saunders et al., n.d.) making this study necessary.

Issues relating to remittances and development in Nigeria have been addressed to some extent by a few research works. Almost all of such works were enclave and did not clearly reflect the Nigerian situation. Examples are works of: Olowa and Olowa (2005), Osili (2007), Babatunde and Martinetti (2010) and those of Nwaru et al. (2011). However, Chukwuoene et al., (2012) did a comprehensive study covering Nigeria but requires validation using a more recent study considering that data for their study were derived in 2004. This study employed data from the General Household Survey conducted in 2010/2011 in addition to the 2004 data. Specifically, this study provided answer to key policy questions such as "does migrant remittances enhance the welfare of the hitherto poor farm households in Nigeria?" The study derived policy implication of its results, and it is laid bare to policy makers. The facts presented are meant to shift the Nigerian nation from the stage of speculation to that of decision making.

\section{MATERIAL AND METHODS}

This section highlights the study area, sampling procedure, data collection and analytical techniques.

\section{Study Area}

Nigeria is the study area with a principal focus on the agrarian sector. Nigeria is a familiar and proximate terrain to the researcher. More so, the recent growth in remittances inflows into the country coupled with the debates about the likelihood of the funds being harnessed for the welfare of the agrarian sector makes this choice apt. Emphasis on the agrarian sector of Nigeria was also important because most Nigerians, approximately twothirds of the population are domiciled in this sector. The agrarian sector is synonymous with the rural areas of Nigeria. It is defined by such criteria as; predominance of agricultural related livelihood, low population density, poor infrastructural services (Yusuf and Ukoje, 2010) and relatively high incidence of poverty. These exclude the nation's state capitals and major cities.

\section{Sampling Procedure}

Cross sectional data were drawn from the General Household Survey-Panel conducted in 2010/2011 and henceforth referred to as GHS (2011). Supplementary cross sectional data were also obtained from the Nigerian Living Standard Survey done in 2003/2004 referred to as NLSS (2004). Both surveys were conducted by the Nigerian Bureau of Statistics (NBS) in conjunction with the World Bank. Amidst other important data, these 
groups of data contain information on remittances received by each household.

The GHS (2011) is a two-stage probability sample. In the first stage, the primary sampling units termed "enumeration areas (EAs)" were selected. Selection was based on probability proportional to size of the total EAs in each state and FCT giving a total of 500 EAs. In the second stage, households were selected randomly using the systematic selection of ten (10) households per EAs giving a total of 5,000 households. However, because the households were not selected using replacement sampling, the final number of households with data in both points in time (post planting and post-harvest surveys) was 4,851 . The NLSS (2004) is a two-stage stratified sampling. The first stage involved the selection of 120 EAs in each of the 36 states and 60 EAs at the Federal Capital Territory (FCT). The second stage was the random selection of five housing units from each of the selected EAs. A random total of 21,900 households responded to the study interview across the country. However, 19,158 households provided consistent information (NBS, 2005).

Subset of the microdata used for this research includes 1070 households from NLSS (2004). NLSS (2004) subset comprised of 982 households who reported receipt of domestic transfers. Also included in the NLSS (2004) subset were 44 households who reported receiving international remittances and 44 who did not report receipt of remittances. From GHS (2011) 158 households were selected (79 reported receipt of international remittances and 79 did not report receipt of remittances). Hence, a total of 1228 households NLSS (2004) and GHS (2011) were used for the analysis. All the remittance recipient households were purposively selected from the NLSS (2004) and GHS (2011). The non-remittance recipients were selected based on nearest neighbour and socioeconomic characteristics matching with one of the selected international remittance recipients' household. That is the researcher selects a non-remittance recipient household if its socioeconomic characteristics are the closest to those of a nearest recipient household.

\section{Data Collection}

Essentially cross sectional secondary data derived from NLSS and GHS were used for this study. Amidst other important data, these groups of data contain information on remittances received by each household. The survey elicited answers for such questions as: has this household received or collected money or goods from absent member during the last 12 months? Has this household received or collected money or goods from any other individual?, list each person name, from whom household received money or goods?, id codes if the person is an absent member of the household, if not a household member, relationship to the household head and sex, were these remittances received on a regular basis?, will you have to repay these?, what was the total amount of cash this household received from this individual during the last 12 months?, what was the total value of food received from this individual during the last 12 months?, what was the value of other goods (nonfood items) received from this individual during the last 12 months where does this individual live, Lagos, etc., abroad (Africa or other)? It also has demographic information on households.

Meanwhile, preliminary and ancillary information (e.g. national remittance data) were retrieved from published books, journals, annual reports, bulletins, progress reports, websites, etc. of relevant organizations. These provided information required for a derivation of the research problems, study objectives and hypotheses, and were also relevant in comparative discussions of the findings of this research.

\section{Analytical Techniques}

Glewwe's (1991) econometric technique as applied by Quartey (2006) was relevant in analysing the effect of remittances on farm households' welfare. The model will also evaluate the effects of other variables on the households' welfare. Glewwe's expressed the model as Eq. (1).

$$
\log \left(U_{i}\right)=\alpha+\sum \beta_{j} X_{i j}+\varepsilon_{i}
$$

The error term, $\varepsilon_{i}$ is assumed to be independent and normally distributed, $U_{i}$ is household utility measurable in terms of the household's real per capita expenditure. $\log \left(U_{i}\right)$ is the logged value of $U_{i}$. The notations $X_{i}$ to $X_{j}$ are a vector of explanatory variables including migrant remittances. The symbols $\beta_{i}$ to $\beta_{j}$ represent the respective coefficients of variables, $X_{i}$ to $X_{j}$; and $\sum$ is the summation sign.

Based on theoretical underpinnings, the model supposes that the goal of households is to maximize utility subject to a budget constraint. Duality theory expresses consumer decisions in terms of expenditure required (cost functions), which depicts the cost of maximizing utility in a given household to attain a certain level of satisfaction. The expenditure required (or cost) to attain a given level of satisfaction depends on the prices of goods and services, characteristics of household members such as their age, sex, etc. More explicitly the poverty profile function portraying factors influencing farming households' welfare was specified as Eq. (2).

$\mathrm{RPC}=\beta 0+\beta_{1} \mathrm{RPR}+\beta_{2}$ Sex $+\beta_{3}$ Age $+\beta_{4}$ Mst $+\beta_{5}$ $\mathrm{Hsz}+\beta_{6} \mathrm{Edu}+\beta_{7}$ Occ $+\beta_{8} \mathrm{RPI}+\beta_{9}$ Ezo $+\beta_{10} \mathrm{Sec}^{+}$ $\beta_{11}$ Rem $+\varepsilon$

Where:

RPC: household's real per capita household consumption (in Naira)

RPR: household's real per capita household remittances (in Naira)

Sex: categorical variable for sex of household head (1 for female, and 0 for male)

Age: age of household head

Mst: dummy variable for marital status of household head ( 1 for married, and 0 otherwise)

Hsz: number of persons living in the household

Edu: Number of years of formal education of household head 
Occ: dummy variable for principal occupation of household head (1 for farming, and 0 otherwise)

RPI: household's real per capita income (in Naira)

Ecz: ecological zone of residence of household (rain forest belt $=1$, Savanna belt $=0$ )

Sec: dummy variable for sector of residence of household ( 1 for rural, and 0 for urban)

Rem: category of remittance received (1 for international, and 0 for domestic)

$\beta_{0}$ : constant intercept.

$\beta_{1}$ to $\beta_{11}$ : parameters of independent variables

$\varepsilon$ : error term

A priori; Age, Mst, Edu, Occ, RPI, Ecz, and Rem have positive effects on the dependent variable, RPC. In contrast, Sex and Hsz and Sec; a priori, have a negative relationship with the RPC.

\section{RESULTS AND DISCUSSION}

This section presents the results and provides a critical discussion while comparing the findings from similar studies

\section{Data Description}

The pooled micro-data of GHS (2011) and NLSS (2004) consist of 4,851 and 19,158 households respectively, giving a total of 24, 009 households. From the pooled sampled, analysis from a sub-sample of 1228 gave the research results. Of the sub-sample 123 (10\%) were international remittance recipients households, 982 (80\%) were domestic remittance recipients households (Table 2). For comparative reason, another 123 (10\%) were non remittance recipients households. Almost 63\% (768) of the households have real per capita consumption of less than 50,000 Naira in the one year survey period. Only $168(13.7 \%)$ of the households had real per capita consumption of at least 50,000 Naira in the one-year survey period. A few, 292(23.7\%) of the households did not report their consumption expenditure. Real per capita income was less than 50,000 Naira in most (866 or $70.5 \%)$ of the households. Only 270 (22\%) of the households had real per capita income of 50,000 Naira or more. About $8 \%$ (92) of the households did not report income. The Table 3 provides further descriptive statistics of the households socioeconomic indicators including remittances variables.

About $60 \%$ (592) of households who reported their principal occupation in the subsample have agricultural activities as their main occupation (Table 2). Hence, the main reference group of the study is the farm households who received migrant remittances. Some (475 or $38.7 \%$ ) of the subsampled households have nonagricultural activities as their main occupation. Selection of households in the two occupational groups provided room for comparative analyses. Meanwhile, 161 (13.1\%) of the households did not report their principal occupation. Also, validating the choice of farming households as the main reference group is the fact that $753(61.3 \%)$ of the subsampled households reside in the agrarian (rural) sector. About 39\% (475) reside in urban areas, providing a basis for comparative study with the rural households.

Table 2: Frequencies and percent distribution of sampled household nominal variables

\begin{tabular}{lrr}
\hline Variable & Frequency & Percent \\
\hline Sex of household head & & \\
$\quad$ Male & 801 & 65.2 \\
$\quad$ Female & 427 & 34.8 \\
Marital status of household head & 508 & 41.4 \\
$\quad$ Not Married & 718 & 58.5 \\
$\quad$ Married & 2 & 0.2 \\
$\quad$ Not stated & & \\
Household's main occupation & 475 & 38.7 \\
$\quad$ Non-Farming & 592 & 48.2 \\
$\quad$ Farming & 161 & 13.1 \\
$\quad$ Not stated & & \\
Household's sector of residence & 475 & 38.7 \\
$\quad$ Urban & 753 & 61.3 \\
$\quad$ Rural & & \\
Household's ecological zone of & & \\
residence & 298 & 24.3 \\
$\quad$ Savannah & 930 & 75.7 \\
$\quad$ Rainforest & & \\
Household's remittance status & 123 & 10 \\
$\quad$ Non-Remittance Recipient & 123 & 10 \\
$\quad$ International Remittance & & \\
$\quad$ Recipients & & \\
$\quad$ Domestic Remittance & 982 & \\
$\quad$ Recipients & &
\end{tabular}

Table 3: Descriptive Statistics of Sampled Households' Scaled Variables

\begin{tabular}{|c|c|c|c|c|}
\hline Variables & Min. & Max. & Mean & $\begin{array}{l}\text { Std. } \\
\text { Dev. }\end{array}$ \\
\hline $\begin{array}{l}\text { Age of household } \\
\text { head (Years) }\end{array}$ & 15 & 99 & 54.12 & 17.7 \\
\hline \multicolumn{5}{|l|}{ Years of } \\
\hline $\begin{array}{l}\text { Educational } \\
\text { experience of } \\
\text { household head }\end{array}$ & 1 & 19 & 8.38 & 4.7 \\
\hline $\begin{array}{l}\text { Household size } \\
\text { (Number) }\end{array}$ & 1 & 23 & 4.15 & 2.9 \\
\hline $\begin{array}{l}\text { Household's real } \\
\text { per capita } \\
\text { consumption } \\
\text { (Naira) }\end{array}$ & 10019 & 995069 & 62305.54 & 97177.8 \\
\hline $\begin{array}{l}\text { Household's real } \\
\text { per capita } \\
\text { income }\end{array}$ & 10149 & 186366 & 29504.06 & 28930.7 \\
\hline $\begin{array}{l}\text { Real per capita } \\
\text { remittances } \\
\text { received by } \\
\text { household } \\
\text { (Naira) }\end{array}$ & 1002 & 1104434 & 20825.46 & 60621.9 \\
\hline
\end{tabular}

Only 224 (18.2\%) of the households had heads with at least 12 years of formal education whereas 341 (27.8\%) had less than 12 years of formal education. Most, 663 (54\%) of the households did not report the number of years of formal education of their household heads. Almost $70 \%$ (845) of the households have heads aged less than 65 years while 383(31.2\%) had heads aged 
65 years or more. Most (801 or $65.2 \%$ ) of the households had men as heads whereas 427 (34.8\%) had women as heads. There were more (718 or $51.5 \%$ ) of the households with married heads than (508 or $41.4 \%$ ) with unmarried heads. A few (2\%) of the households did not report marital status of their heads. Majority, 879 (71.6\%) of the households had less than six members whereas 349 (28.4\%) had at least 6 members.

\section{Effect of international remittances on the recipient households' consumption}

Three functional forms (linear, semi-log and double -log) of multiple regression model were tried. The linear form fitted the data the most because of the significance of its F- values, highest R-squared value, least standard error, and largest number of significant variables (Table 4). Linear multiple regression model was therefore, the best equation for determining the effect of international migrants' remittances and other factors on farm households' real per capita consumption. Table 4 presents the results of the model (By the rule of thumb, R-value of 0.842 as in the Table 4 implies a very strong correlation of the independent variables with the dependent variable). The adjusted R- square was 0.699, implying that the model accuracy was $69.9 \%$. That is $69.9 \%$ of the variation in real per capita consumption can be accounted for by international migrant remittances and other exogenous variables specified. The F-statistic (0.00) is significant at $5 \%$ level $(\mathrm{F}=67.92)$, further validating the fact that the independent variables significantly explain the variations in real per capita consumption of Nigerian farm households.

Graphical plots of the expected cumulative probabilities of the dependent variable against its observed cumulative probabilities present a curve that is around the regression line. The graph showed that the data sets on household real per capita remittances were normally distributed allaying spuriousness in the model outputs.

The results showed that four of the exogenous variables included in the linear multiple regression model were significant determinants of real per capita consumption. These variables include: households' real per capita remittances (RPR), sex of household head (Sex), age of household head (Age) and main occupation of household (Occ). Based on their respective beta coefficient as in Table 4, we ranked all the independent variables according to the relative intensities of their effects on households' real per capita consumption (dependent variable). The relative intensities of the effects of the significant variables $(\mathrm{P}<0.05)$ on households' real per capita consumption were: real per capita remittances (RPR), $59.69 \%$; sex of household head (Sex), 6.20\%; age of household head (Age), 6.20\%; and main income generating occupation of household (Occ): $7.75 \%$ (Table 4). Clearly, household real per capita remittances is a lead factor in households' welfare across the survey periods.
With positive coefficient (0.86) on real per capita remittances (RPR), the result shows that an increase of real per capita remittances of 1000 Naira will cause per capita consumption to increase by 855 Naira. Therefore, we reject the null hypothesis and accept the alternative hypothesis that migrant remittances have significant positive effect on farm households' welfare.

\section{Discussions}

The permanent income and life cycle models postulate that, as opposed to a permanent increase, a temporary increase in income is expected to yield a smaller increase in consumption. Households would often spread a temporary increase in income over lifetime consumption. However, this result show that the respondents threat remittances like permanent income because almost 100\% (or exactly $86 \%$ ) of remittances were spent on short term consumption. The result implied that the remittance recipients save or invest only $14 \%$ of their remittances and do not spread their most of their consumption from remittance income over a lifetime. This result has two sides of the coin. First, if the short term increase in consumption of the remittance recipients stimulates increased investment, then it will culminate in a sustainable welfare. Second, if the short-term increase in consumption by remittance recipients does not stimulate an increase in supplies, then increased welfare will be temporary.

Similar finding by Chukwuonne et al. (2012) indicated that remittances reduce the level, depth and severity of poverty in Nigeria. Nwaru et al. (2011) in their study of South Eastern Nigeria affirmed that the remittance recipient households had higher welfare than the non-recipient households. Again, Quartey and Blankson (2004) observed that remittances improve household welfare and have become an important source of income for consumption smoothing in Ghana. Zhu et al. (2008) found that remittances spending are mainly for consumption purposes in China. In Nepal, households that receive remittance spend more on consumption purposes and less for investment goods (Dharkal, 2012). Cuong (2009) found that international remittances helped the recipients increase savings and production investment in Vietnam. From same study he found that it was the internal remittances that increased per capita food consumption expenditure and per capita expenditures on health care, education and other nonfood consumption. In Nigeria farm households will continue to spend most of international and domestic remittances on welfare, given the severity of poverty in the rural areas where they reside.

Remittances will change it role in rural areas of Nigeria from consumption to investment once a benchmark in rural welfare is reached. The government needs to direct a quota of her public spending towards rural development in order to reach this benchmark in the near future. 
Table 4: Effects of international migrant remittances and other variables on farm household real per capita consumption (RPC)

\begin{tabular}{|c|c|c|c|c|c|}
\hline Variable & Variable defined & Coefficient & beta & $\mathrm{t}$ & $\begin{array}{r}\text { Contribution to } \\
\text { variation } \\
\text { in RPC (\%) } \\
\end{array}$ \\
\hline & (Constant) & 34091.39 & & & \\
\hline RPR & Household's real per capita remittances (Naira) & $.86^{*}$ & .77 & 23.73 & 59.69 \\
\hline Sex & Sex of household head & $-9218.14 *$ & -.08 & -2.21 & 6.20 \\
\hline Age & Age of household head (years) & $-283.97 *$ & -.08 & -2.39 & 6.20 \\
\hline Mst & Marital status of household head & -6284.04 & -.04 & -1.06 & 3.10 \\
\hline Edu & Educational experience of household head (years) & 247.25 & .02 & .63 & 1.55 \\
\hline Hsz & Household size & -623.46 & -.04 & -1.06 & 3.10 \\
\hline Occ & Main income generating occupation of household & $-10043.03 *$ & -.10 & -2.68 & 7.75 \\
\hline RPI & Household's real per capita income & .03 & .010 & .320 & 0.78 \\
\hline Ezo & Ecological zone of residence of household & 5488.18 & .045 & 1.296 & 3.49 \\
\hline Sec & Sector of residence of household & 4761.40 & .044 & 1.193 & 3.41 \\
\hline Rem & Remittance category & 10633.87 & .045 & 1.342 & 3.49 \\
\hline
\end{tabular}

R: 0.842, R-square: 0.678, Adjusted R-square: 0.669, F-statistic: 67.92*

* Significant at 5\% probability level.

Source: Results of data analyses from GHS (2011) and NLSS (2004)

The categorical variable "category of remittances (with dummies: international remittances $=1$, domestic remittances = 0)" was not a significant factor in household welfare. Although the volume of remittances is a very important factor, international remittances does not have more effect on the sampled households' welfare than internal remittances. Although money from all sources are fungible or can contribute to consumption, a priori, farm households threat money from different sources differently. Drawing from the permanent income and life cycle hypotheses, international remittances are temporary income that farm households spread over a life time consumption and should contribute less to their short term consumption (welfare) than domestic remittances which is a relatively longer term income.” Relative to domestic remittances, international remittances are temporary income because attachment of origin households to international remitters weakens over time, whereas attachment to domestic remitters remains intact for a long period of time

Similar study by Chukwuonne et al. (2012) found that international remittances have more poverty reducing effect than internal remittances, but affirmed the need to verify the finding with a more robust international remittance data other than the NLSS. Results verification will be necessary because certain studies demonstrate that there are many more beneficiaries of domestic than international remittances in Africa (Sander and Miambo, 2005).

Meanwhile, the result is further corroborated by Siddiqui's (2008) findings that the main role of remittances in some poorer regions. This role of remittances is notable in sub-Saharan Africa and South Asia, where they are mostly used to stimulate consumption, as well as contribute to poverty alleviation. Supporting these findings is the fact that 61 percent of a group of Nigerians in diaspora (surveyed by DFID, 2005) remit for sustenance of those at home. Babatunde and Martinetti (2010) also found that in Nigeria households who received remittances had better access to food and nutrition.

\section{CONCLUSIONS}

Increased remittances contributed almost a proportionate increase in welfare of farm households. Given that data used for the analyses were cross sectional, the result showed that a greater portion of remittances goes into the farm households' short-term consumption or welfare.

\section{Recommendations}

Public spending needs to reflect the plight of the highly impoverished rural households farming on marginal lands and producing food at less than subsistence level. If this is done, then remittances will gradually become a significant contributor to farm household investment and savings than to consumption. Programmes planning and implementation to encourage the entrepreneurial drive among the rural farm families is necessary. Where these programmes already exist they should be strengthened. Stakeholders in such programmes will have to include: multilateral and bilateral agencies, government at all levels, civil society organisations, households and the individuals themselves whether they are remittance recipients or not, should be involved.

Entrepreneurship development at all levels will multiply the effects of remittance income on the economy thereby keeping household welfare increasing and sustained. The reverse situation is that remittances will be continually spent on imported manufactured goods and services. This reverse situation can deindustrialise the nation, yielding the "Dutch disease effect". This effect can further lead to a downward trend in per capita income and household welfare.

Finally, Nigerian households' data on remittances are inadequate to study the long-term welfare effects, as well as the deferential welfare effects of international remittances and domestic remittances. Therefore, thematic household panel surveys on international and 
domestic remittances and their effects on the economy will have to form one of the courses of action of Nigerian Bureau of Statistics. The Banking sector with the Central Bank of Nigeria as the spearhead will have to the plan and implement these surveys. Supports from multilateral agencies interested in remittances as a development strategy is necessary with respect to design, implementation, control and financing of these surveys.

Acknowledgments: I appreciate the support of Canadian Bureau of International Education and the Department of Foreign Affairs and International Trade, Canada. The joint Scholarship awarded by both institutions under the Student Exchange Program enabled me to carry out this research as a part of my Ph.D. work at the Department of Economics, University of Ottawa, Canada. I acknowledge the support of Professor Gilles Grenier, my Exchange Program Advisor at the University of Ottawa and those of my academic supervisors who are joint authors of this paper: Professor Noble J. Nweze and Professor Chukwuemeka J. Arene both of University of Nigeria.

\section{REFERENCES}

ADAMS, H. R. - PAGE, J. (2005). Do international migration and remittances reduce poverty in developing countries? World Development. 33(10), 16451669. http://dx.doi.org/10.1016/j.worlddev.2005.05.004

ADDISON, E. K. Y. (2004). The macroeconomic impact of remittances in Ghana. Research Department. Bank of Ghana.

BABATUNDE, R. O. - MARTINETTI, E. C. (2010). Impact of remittances on food security and nutrition in rural Nigeria. Paper prepared in collaboration with visiting scholar at the Centre for International Cooperation and Development. Department of Public Economics, University of Pavia, Italy.

CHUKWUONE, N. - AMAECHINA, E. - IYOKO ENEBELIZOR, S.E. - OKPUKPARA, B. (2012). Analysis of impact of remittances on poverty in Nigeria. Poverty Economic Policy (PEP) Research Paper. Poverty and Economic Policy PMMA Network.

CUONG, N. V. (2009). The impact of international and internal remittances on household welfare: evidence from Vietnam. Asia-Pacific Development Journal. 16 (1).

DFID (2005). Informal remittance systems in Africa, Caribbean and Pacific (ACP) Countries. Emerging Markets Group (EMG) Ltd. London. Retrieved from http://r4d.dfid.gov.uk/PDF/Outputs/ECPREP/InformalRemittanceSummary.pdf

DHARKAL, S. (2012). International remittances, household expenditures and saving: evidence from Nepal. Master Thesis of Department of UMB, School of Economics and Business. University of Norwegian Life Sciences.

DUONG, T. D. (2003). Micro-determinants of household welfare, social welfare, and inequality in Vietnam. Retrieved September 2010 from: http://www.grips.ac.jp/vietnam/VDFTokyo/Doc/So cialBook1Chapter6-1.pdf
GLEWWE, P. (1991). Investigating the determinants of household welfare in Côte d'Ivoire', Journal of Development Economics, Vol. 35, pp. 307-37.

GUPTA, S. - PATTILLO, C.A. - S. WAGH, (2009) Effect of remittances on poverty and financial development in Sub-Saharan Africa. World Development. Vol. 37, No.1: pp. 104115. http://dx.doi.org/10.1016/j.worlddev.2008.05.007

IFAD (2007). Worldwide remittance flows to developing and transition countries. Sending Money Home. Retrieved from www.ruralpovertyportal.org

NBS (2005). Nigerian Living Standard Survey. September, 2003 to August, 2004.

NIGERIAN BUREAU OF STATISTICS (NBS) (2011). General Household Survey-Panel. 2010/2011.

NWARU, C. J.- IHEKE, O. R. - ONYENWEAKU, C. E. (2011). Impact of Migrant Remittances on the Welfare of Arable Crop Farm Households in South Eastern Nigeria. Human Ecology Review 18 (2). Society for Human Ecology.

OLOWA, O. W. - OLOWA, O. A (2008). Remittances, inequality and poverty: Evidence from rural south western Nigeria. Journal of Social and Policy Issues. International Research and Development Issues, Uyo. 5(3), 92-99

OROZCO, M. \& MILLIS, B. (2007). Remittances, competition and fair financial access opportunities in Nigeria. A publication United States Agency for International Development. USA.

OSILI, U. O. (2007).Understanding migrants' remittances: Evidence from the U.S.-Nigeria migration survey. Department of Economics, Indiana University Purdue University Indianapolis.

PLEITEZ-CHAVEZ, R. A. (2004). Remittances as a strategy to cope with systemic risk: Panel results from rural households in El Salvador. Dissertation. Ohio State University.

QUARTEY, P. - T. BLANKSON. (2004). Do migrant remittances minimize the impact of macrovolatility on the poor in Ghana? Global Development Network. 2004.

QUARTEY, P. (2006). The impact of migrant remittances on household welfare in Ghana. AERC Research Paper 158. African Economic Research Consortium, Nairobi. August 2006.

SANDER, C. - MIAMBO, S. M. (2005). Migrant remittances in Africa: a regional perspective. Remittances: development impact and future prospects. (Eds: Miambo, S. M. \& Ratha, D.). The World Bank, Washington DC.

SAUNDERS, J.- AHIADEKE, C. - ANARFI, J. K. (n.d). Ghana: Till to tiller: Linkages between international remittances and access to land. FAO Corporate Document Repository.

SEILER, E. J. (1998). Transfers, Remittances and Borrowing in Village India (Doctoral dissertation, The University of Chicago, 1998). Dissertation Abstracts International, 59 (07), p. 2630.

SIDDIQI, M. (2008). The global remittances boom: billions pour into Africa. In: African Business. Tuesday, January 1, 2008 
United Nations Organisation (UNO) (2003). Protection of migrants' rights, role of remittances in development. UN Sixtieth General Assembly Second Committee $15^{\text {th }}$ and $16^{\text {th }}$ Meetings. GA/EF/3122

YUSUF, R.O. - UKOJE, J.A. (2010). Recent observations on rural geographic research in Nigeria.
Research Journal of Environmental and Earth Sciences. Maxwell Scientific Organization. 2(2), 76-81.

ZHU, Y.- WU, Z.- WANG, M.- DU, Y. - CAI, F. (2008). Do Migrants Really Save More? Understanding the Impact of Remittances on Savings in Rural China. Paper presented at Chinese Academy of Social Sciences. 20Mar-08. 